\title{
The Republic of Indonesia Territorial Atlas as Geo-literation Tools for the Adolescents
}

\author{
Fakhruddin Mustofa ${ }^{a,{ }^{*}}$, Ellen Suryanegara ${ }^{b, *}$, Niendyawati ${ }^{c}$, Mulyanto Darmawan ${ }^{\text {d }}$ \\ ${ }^{a}$ Geospatial Information Agency, The Republic of Indonesia, uddin_mustofa@yahoo.com \\ ${ }^{b}$ Geospatial Information Agency, The Republic of Indonesia, ellen.surya@gmail.com \\ ${ }^{c}$ Geospatial Information Agency, The Republic of Indonesia, niendya_salam@yahoo.co.id \\ ${ }^{d}$ Geospatial Information Agency, The Republic of Indonesia, drmoel2011@ gmail.com \\ * Corresponding author
}

\begin{abstract}
:
As an independent country and has a long history that forms The Unitary State of The Republic of Indonesia, introduction to the territory and history is very necessary for Indonesia's young generation, especially for adolescents. Various efforts were made by the Government of Indonesia to provide a territorial comprehension in order to make the younger generation understand about the circumstances of their country. One effective way is through Territorial Atlas of The Republic of Indonesia, which is the result from collaboration project between Geospatial Information Agency and Ministry of Education and Culture of Indonesia. This atlas is intended towards the benefit of teenage children, who are taking middle education level between the ages of 12-15 years. It is necessary for children at that age to be equipped with spatial intelligence related to the territorial comprehension of Indonesia, the historical development of the Republic of Indonesia, and also the natural resources potential of their country.
\end{abstract}

This comprehension is needed considering that adolescence is a vulnerable age who require self-actualization, so they need to get a correct understanding of the NKRI region in order to foster the sense of nationalism. On the other hand, the important reason for production the Territorial Atlas is due to the rapid growth of development and the administrative area expansion, especially since the era of regional autonomy, was applied. Furthermore, another reason is that the atlases on the market were not up to date and geometrically did not obey the cartographic principle appropriately. This will cause a misconception for the reader, especially students in the middle school if they receive incorrect information.

Therefore, it is important to produce a territorial atlas that uses the mapping principle and correct geospatial data and information. The method used in production the territorial atlas is using the GIS method complemented by literature studies and focused group discussions with education and geospatial experts. In general, the atlas is a compilation of coherent and comprehensive geospatial information regarding 34 provinces in Indonesia, the history of the Republic of Indonesia, introduction of neighboring countries and also equipped with narratives and interesting photographs/images.

The results of this activity are in the form of The Republic of Indonesia Territorial Atlas which has been adjusted based on the applicable curriculum and will be disseminated to approximately 3,500 Junior High Schools in all regions of Indonesia in print and digital format. It is expected that through the atlas, the spatial comprehension of young people towards the NKRI region will be better and easier.

Keywords: atlas, education, geospatial, geo-literation, region, territorial

\section{Introduction}

The Unitary State of the Republic of Indonesia was declared as an independent region on August 17, 1945, through a long struggle of the people. Indonesia is also an Archipelagic State which shares its borders with 10 other countries and territories; namely, Malaysia, Papua New Guinea, Timor-Leste, India, Thailand, Singapore, Vietnam, The Philippines, Palau, and Australia. Therefore, as a sovereign country and has a long history that forms the Unitary State of the Republic of Indonesia, introduction of the territory and history is very necessary for Indonesia's young generation, especially for adolescents. At this time there was a significant development in physical, emotional, personality, social, moral, and intellectual. This development is an important process of forming one's self construct in a family environment or society in general.

The adolescent needs to be provided with spatial intelligence related to territorial and historical comprehension about the civilization of Indonesian people. Both of them inseparable from the geographical characteristic, natural resources potency, social-culture, as well as the disaster problems in Indonesia. This 
comprehension is needed considering the adolescents are in a vulnerable age and need self-actualization, so it needs to get a correct understanding of the Indonesian region.

Spatial intelligence can be optimized through education. Spatial education needs to be intensified by educators and those who engaged in geospatial information or earth science. Geospatial information is one of the important sciences for the development of human resources, especially for the next generation in order to add knowledge about their archipelagos insights. This will encourage an increase in geographical literacy.

Various efforts have been made by the Government of Indonesia to provide comprehension of territorial aspects so that the younger generation can better understand the circumstances of the country. Since 2016, the Government of Indonesia through the Ministry of Education and Culture has intensified the National Literacy Movement as part of the implementation of the Minister of Education and Culture Regulation No. 23 of 2015 concerning the Character Enhancement. One of the goals of the National Literacy Movement initiated by the government towards the adolescent is to understand and empathize with the living space around them. Geoliteration itself is the ability to process and understand the information of the surrounding space while performing reading and writing in geography.

According to Indonesian Comprehensive Dictionary, literacy is the ability to write and read, the ability of individuals to process information and knowledge for life skills. Literacy is also knowledge or skills in certain fields or activities. Therefore, Geoliteration in this matter referred to the ability of individuals to process information and knowledge or skills in the field of geography or geoscience to improve the quality of life.

According to Bachtiar (2018), geo-literation provides an understanding of where people live, how people are connected with other people in many places, these are expected to be a source of inspiration in developing personalities and fostering a supported feeling, developing the value of citizenship that love the nation. Geo-literation also bridges comprehensions of rules that absolutely obeyed by its citizens. Geography is more as a catalyst that can facilitate to absorb the understanding of self-identity and other people, about the differences between various national cultures in various parts of the world to achieve peaceful coexistence in diverse societies. This is in accordance with National Geographic (2012) that adopted geo-literacy as a new term for a long-standing idea consisting of three components: interactions, interconnections, and implications. It is the ability to use geographic understanding and geographic reasoning to make farreaching decisions.

One effective way to improve the geo-literation capabilities in society, especially in adolescents, is through increasing the quality of educational books related to geoscience, one of which is Atlas. Atlas is one of the educational instrument which becomes the front gate that makes students it easier to understand about a region, alongside wall map products as the other geographical teaching instrument. Teaching instrument is a tool to assist in conducting interactions with students and to facilitate students to understand the lessons that must be mastered, which in the end is expected to improve the quality of learning outcomes. Moreover, education in mapping and geography forms part of the process of establishing a map-conscious society (Klaas Villanueva, Proceedings of ICA 1997).

Therefore, it is important to produce a territorial and historical atlas that uses the cartographic principle and correct geospatial data and information. This is considering the atlas circulating on the market is not up to date and geometrically did not obey the cartographic principle appropriately. The producers and publishers of maps and atlases on the market also did not concern towards the compatibility level of the content material to the applicable curriculum. The rapid growth of development and the administrative area expansion, especially since the era of regional autonomy was implemented, also encouraged an increase in the need for the latest geospatial information.

Because of this matter, Geospatial Information Agency with the Ministry of Education and Culture of the Republic of Indonesia collaborated to produce the Regional and History Atlas of the Republic of Indonesia in accordance with the curriculum, in this case, it is Junior High School curriculum. This is in accordance with the definition of adolescence by Hurlock (1980) which divides adolescence period into two parts, that is early adolescence and late adolescence. Early adolescence lasts around the age of 13 to 16 or 17 years. Thus in general, Junior High School students are grouped in early adolescence. The goals of this research are:

- Mapping Indonesia's territory and history in a structured manner; and

- Arrange thematic maps of territory and history into an atlas as an educational instrument for Junior High School students.

\section{Materials and Method}

\subsection{Conceptual Framework Cartography}

Taylor, 1991 (in Kraak \& Ormeling, 2003) defines cartography as "the organization, presentation, communication and use of geo-information in the form of graphics, digital or tangible formats. It can cover all steps from data preparation to the end user by creating maps and results related to spatial information". The implementation of cartographic principles is also needed to minimize the misinterpretation of original information in the form of spatial data.

\section{Atlas of Education}

An atlas is a systematic and coherent collection of geographical data, in analogue or digital representing a particular area and/or narrative, together with tools for 
navigation, information retrieval, analysis and presentation (Koop, 1993). Ormeling on ACI Proceeding (1998), stated Atlas structure refers to the basic framework according to wich the maps have been incorporated in the atlas. It is based on the emphasis on specific areas or map themes and on the sequence in which these maps follow each other.

School atlas is an atlas produced for educational purposes. Cartographic requirements for school atlases are the structures should follow the school curriculum. The emphasis on specific area and themes should also follow the directives of the educational authorities (Ormeling, 1998).

\section{Junior High School Curriculum on Social Sciences}

The education curriculum in Indonesia is currently arranged and developed using learning strategies with contextual approaches, namely Contextual Teaching and Learning (CTL). CTL is a learning concept that helps teachers and students in linking subjects that is taught/learned with real situations in their learning environment. Like other learning strategies, contextual learning is developed with the aim that learning can be more productive and meaningful without having to change the curriculum and existing order (Setiawan et al., 2016). In the Junior High School Curriculum on Social Sciences, the learning material is presented in an integrated manner, not separated in the field of science of Geography, History, Economics, or Sociology. Geography is used as a basis considering all events and activities bound by location. The aim is to emphasize the importance of spatial connectivity in strengthening the nation. Historical, sociological, cultural and economic studies are presented to support the formation of stronger connectivity. Junior High School consists of 3 levels of education, $7^{\text {th }}, 8^{\text {th }}$, and $9^{\text {th }}$ Grade. Each level has a different level of social science study.

\section{$7^{\text {th }}$ Grade Social Science Curriculum}

In $7^{\text {th }}$ grade, the subject discussed towards the explanation of maps, atlases, and globe, forms of the earth, geographical conditions and population of Indonesia, symptoms in the atmosphere and hydrosphere, land use and economic activities. Regarding history, learning materials for $7^{\text {th }}$ grade are studying about life in the prehistoric period in Indonesia, the development of society during the Hindu-Buddha era until the Islamic period in Indonesia and the development of society in European colonial period.

\section{$8^{\text {th }}$ Grade Social Science Curriculum}

Learning materials of social science in $8^{\text {th }}$ grade is the physical condition of the geographical area with population activities, the development of colonialism and western imperialism, history of the formation process of national awareness and the development of the Indonesian national movement, events circa proclamation era and formation of the Republic of Indonesia, and preparation for Indonesian independence.

\section{g $^{\text {th }}$ Grade Social Science Curriculum}

The Social Sciences material in $9^{\text {th }}$ grade discussed towards the patterns and shapes of the earth's surface, the geography of Southeast Asia, along with the continents and oceans. Regarding history, the material discussed towards the impact of World War II for Indonesia, the struggle to defend Indonesia's independence, the political and economic events of Indonesia post recognition of sovereignty, the struggle of the Indonesian nation to defend West Irian, the events of the national tragedy, the end of the New Order and the birth of Reform Era, and about international institutions and the role of Indonesia.

\subsection{Method}

The method used in this research to produce Territorial and Historical Atlas is using the Geographic Information System (GIS) software. Furthermore, this research complemented by literature studies Focus Group Discussions (FGD) with Junior High School education experts along with geography and history experts. The base map used is the Indonesian Topographic Scale 1: 250,000 . The design and layout process of the atlas book is done using Adobe InDesign software. The general flow of atlas production can be seen in the picture below.

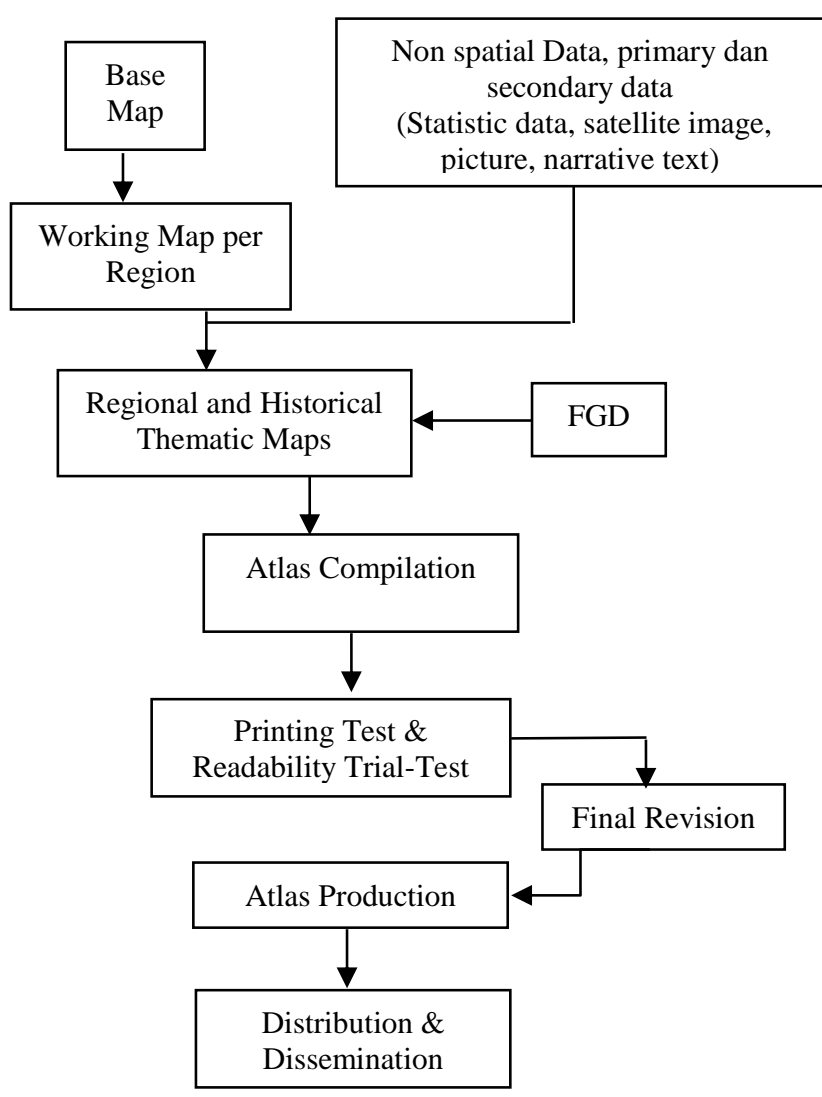

Figure 1. General Flowchart of the Atlas Production Method

\section{Results and Discussions}

The production of Territorial and Historical Atlas has a strategic meaning because it combines two dimensions, which is spatial (space) and time. The spatial 
dimension means describing the circumstances of territory, both the physical and the resources above it, while the dimension of time means informing each event within a certain time frame presented in the map. Both information is very useful as literacy materials for educational purposes.

In general, compulsory education in Indonesia is divided into 3 levels, namely Elementary School (6 years), Junior High School (3 years), and Senior High School (3 years). The necessity for geospatial and historical information at those various levels is formulated in a national curriculum. Two basic things in the curriculum are core competencies and basic competencies. Core competencies are related to the nature of learning, while basic competencies are technical operations.

Geospatial information directly supports the various levels of education in Indonesia. The results of this study focused on the support of geospatial information for junior high schools in the form of Atlas. There are two key related to the importance of atlas to be part of learning literacy in the class, the first is to understand the spatial aspects and connectivity between spaces, the second is to understand the history from prehistoric period until the Reform Era. These are the fundamental part of the themes that will be presented in the atlas.

\subsection{Making Basic (Working) Maps}

The base map becomes the first part of the atlas production. The basic map obtained from the Indonesian Topographical Map scale 1:250,000. This map has 8 elements, which is coastlines, hypsography/contours, waters, topographical names/ toponym, boundaries, transportation and utilities, buildings and public facilities, and land cover. Related to the atlas production, some of these layers are chosen based on the purpose. For example for coastlines, hypsography/contours, waters, topographical names/toponyms, territory boundaries, transportation and utilities, are selected to produce Indonesian map and the 34 provinces. For historical maps, the elements chosen are generally coastlines, administrative boundaries, and toponyms.

Students are also introduced to information of the world and Indonesian regional through maps. The database is obtained from world Shuttle Radar Topography Mission (SRTM) in low resolution and unpaid shapefile data. The working map is compiled from both data, then a generalization process is carried out to produce world map information, continental maps, and maps of the Southeast Asian region. The introduction of areas outside the country of Indonesia is very important because in the Junior High School curriculum it is necessary to understand the spatial aspects and connectivity between regions. Some world objects related to well-known regions were also presented as literacy materials, for example, the introduction of the Panama Canal and the Suez Canal. Both canals are the arteries between the world's main waters. Examples of basic maps for the atlas that have been processed from
Indonesian topographic maps can be seen in the picture below.

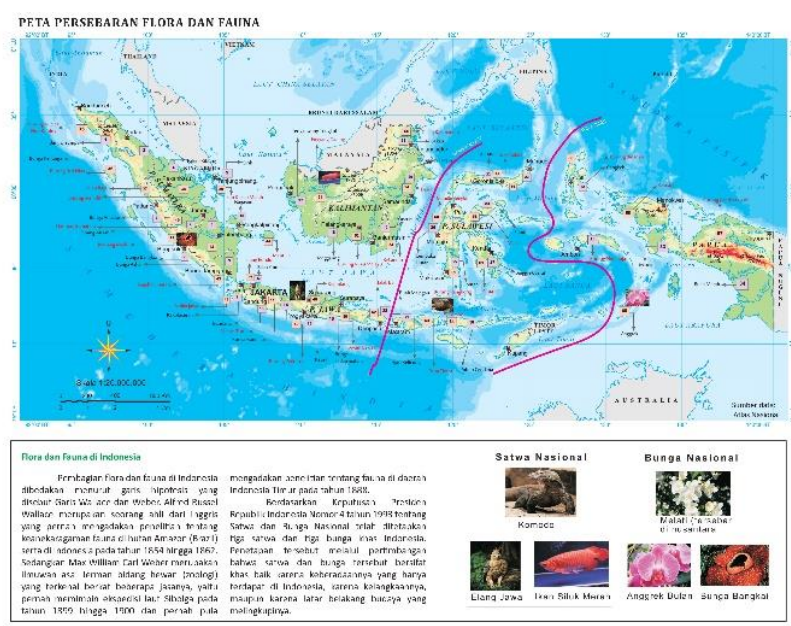

Figure 2. Examples of Indonesian natural resources base map

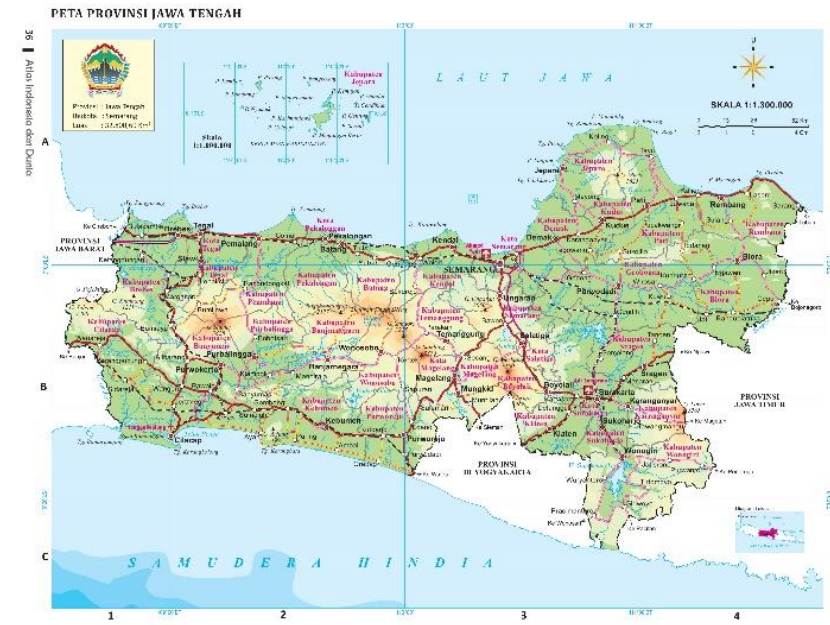

Figure 3. Example of Central Java Province base map

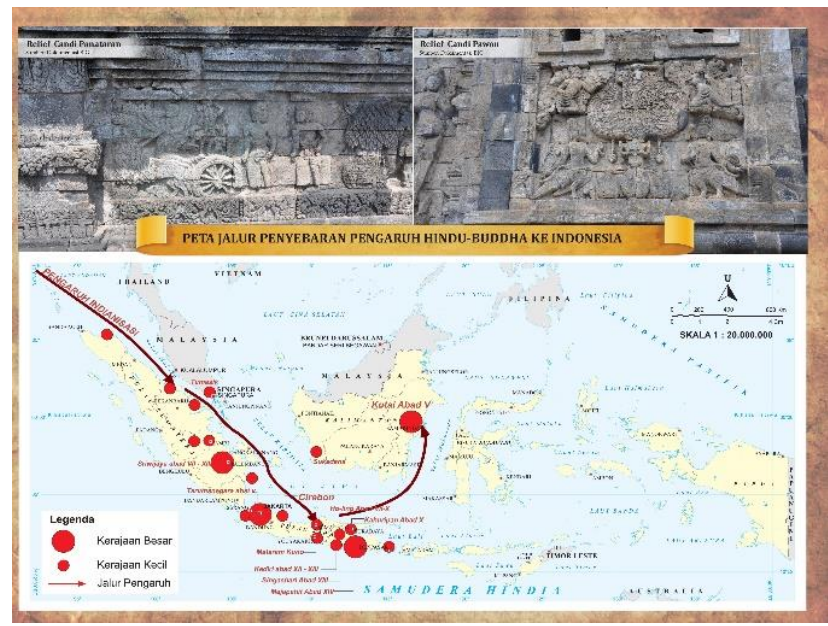

Figure 4. Examples of thematic aspects of history base map

\subsection{Territorial and Historical Atlas Structure}

Atlas is a structured, coherent, and comprehensive geospatial information of particular thematics. Atlas is not just a stack of maps that are not connected to each 
other. This is the advantage of atlas compared to map which only contained one theme information.

Territorial and Historical Atlas are built with ordered structures that are connected to each other. This is attempted to improve students' understanding of the territory and history of Indonesia in accordance with the development of age and level of knowledge. The Territorial Atlas structure begins with the introduction of the Indonesian territory and its natural resources, followed by an understanding of the large islands namely Sumatra, Java, Kalimantan, Sulawesi, Central Nusa Tenggara, Maluku Islands, and Papua. For Historical Atlas, the structure was built based on the periodization of the historical period in Indonesia. The structure of Territorial and Historical Atlas is generally arranged as follows.

\begin{tabular}{|c|c|}
\hline Section & Main Theme \\
\hline Preliminary & $\begin{array}{ll}- & \text { Author List } \\
\text { - } & \text { Table of Contents } \\
\text { - } & \text { Greetings } \\
\text { - } & \text { How to read maps } \\
- & \text { General Legend }\end{array}$ \\
\hline $\begin{array}{l}\text { Introduction to } \\
\text { Regional } \\
\text { Resource Maps }\end{array}$ & $\begin{array}{ll} & \text { Indonesian Map } \\
\text { - } & \text { Administrative Map } \\
\text { - } & \text { Population map } \\
\text { - } & \text { Rainfall Map } \\
\text { - } & \text { Flora and Fauna Distribution Map } \\
\text { - } & \text { Volcanoes Distribution Map } \\
\text { - } & \text { Mineral \& Energy Resources Map }\end{array}$ \\
\hline $\begin{array}{l}\text { Indonesian } \\
\text { Regional Maps }\end{array}$ & $\begin{array}{l}\text { - } \text { Mainland Maps (Sumatra, Java, } \\
\text { Kalimantan, Sulawesi, Bali } \\
\text { Nusatenggara, Maluku Islands, and } \\
\text { Papua) } \\
\text { - } \text { Provincial Maps (each } 34 \text { province) }\end{array}$ \\
\hline $\begin{array}{l}\text { World Regional } \\
\text { Maps }\end{array}$ & $\begin{array}{l}\text { - Wolrd Map } \\
\text { - European map } \\
\text { - Asia } \\
\text { - Australia } \\
\text { - Afrika } \\
\text { - Amerika } \\
\text { - South East Asia }\end{array}$ \\
\hline
\end{tabular}

Table 1. Territorial Atlas Structure

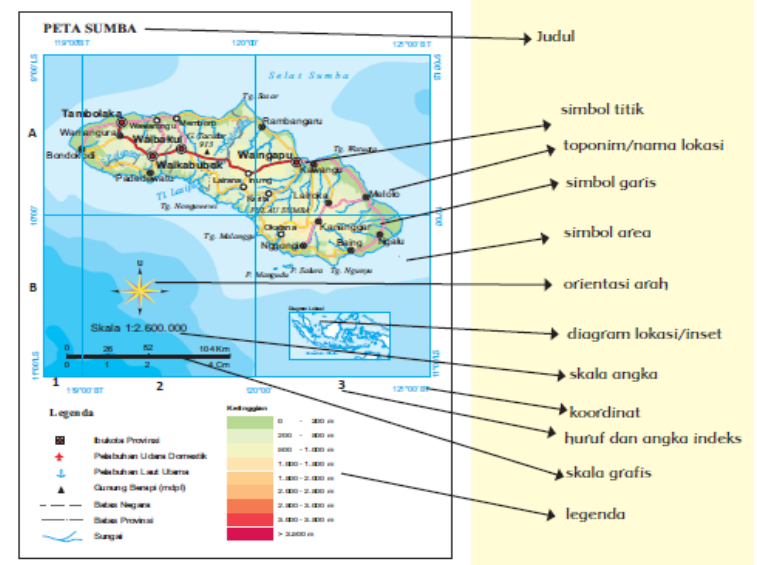

Figure 5. Examples of Map Reading Instrukctions

\begin{tabular}{|l|l|}
\hline Section & Main Theme \\
\hline \multirow{4}{*}{ Preliminary } & - Author List \\
& - Table of Contents \\
& - Greetings \\
& - How to read maps \\
& - General Legend \\
\hline & - Prehistoric Period \\
& - Classical Indonesia: Hindu-Buddhist \\
& - Cultural Era \\
& Erassical Indonesia: Islamic Cultural \\
Indonesian & - European Colonialization Period \\
Historical & - National Awakening Period \\
Periodization & - Japanese Occupation Period \\
& - Revolution to Defend Independency \\
& Period \\
& - National \& International Events after \\
& independence \\
\hline
\end{tabular}

Table 2. Historical Atlas Structure

In some particular pages, students are introduced to important additional information. As an example is the existence of the Suez and Panama Canal. It is expected that regionally, students will recognize the connectivity between the continents and the wide ocean through understanding information about the two Canal. The word 'connectivity between spaces' is one of the mandates in the 2013 Education Curriculum that applies in Indonesia.

\section{Mengenal Terusan Suez}
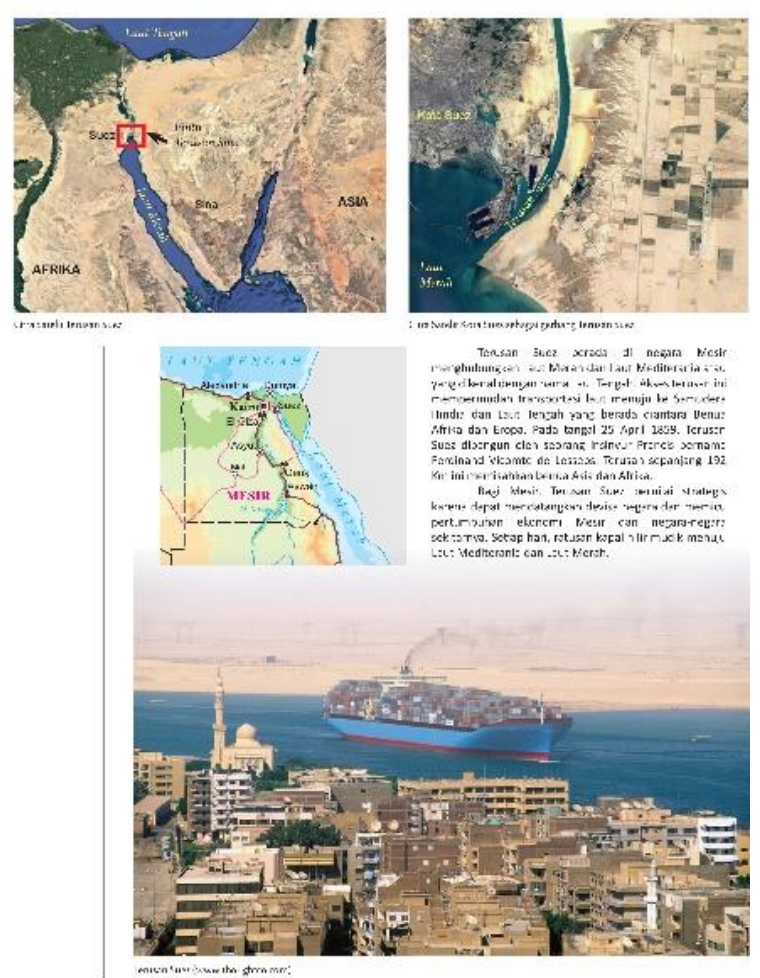

Figure 6. Introduction of the Suez Canal 


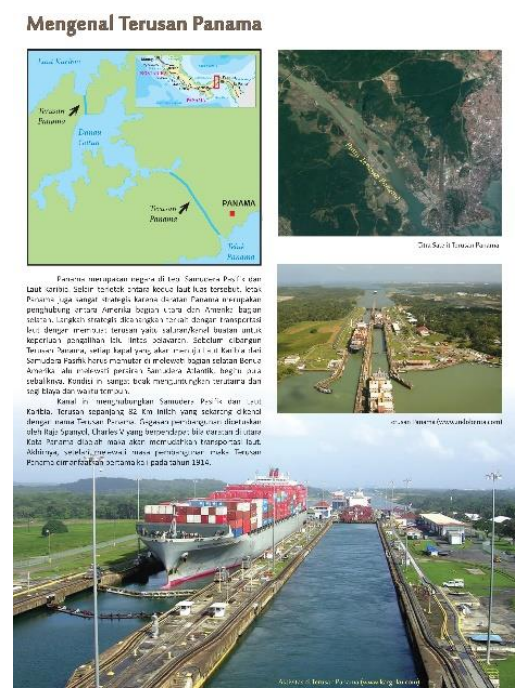

Figure 7. Introduction of the Panama Canal

\subsection{Focus Group Discussion (FGD)}

To produce a quality atlas, it requires the involvement of experts in cartographic, geospatial, historians, graphic design, and Junior High School teachers/educators to formulate concepts and proceed to the technicalities of making an atlas. Focus group discussions are a method of exchanging ideas/knowledge and sharing information about updated regional conditions, full-fledged/official history information, and the suitability of the themes with the applicable Junior High School curriculum.

The discussion is held regularly every three weeks in a period of 6 months. Each informant gave input in descriptive and narrative concepts, then operationalized by the map team into geospatial information. This is considering that the results of spatial data presentation, especially those relating to historical data, need to be evaluated by experts to check and read up whether the interpretation of historical data from a phenomenon has been correct and accurately pictured in the form of spatial data.

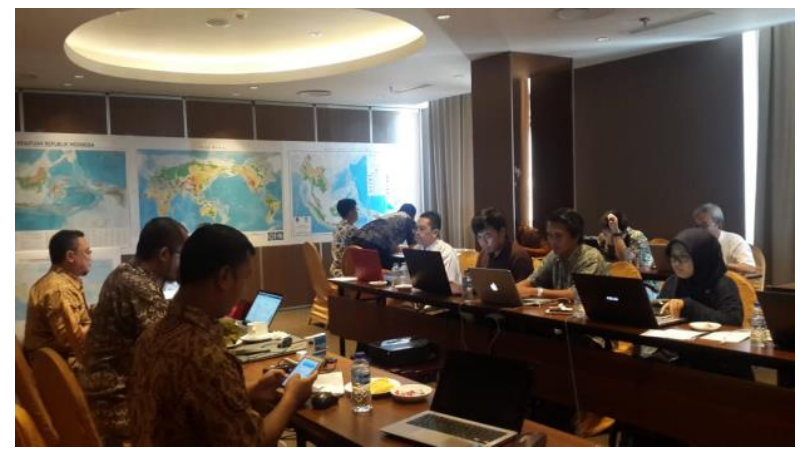

Figure 8. FGD for Atlas production

\subsection{Database, Map Layout, and Atlas Presentation}

The databases of maps in the atlas are arranged using the gdb (geodatabase) and shp (shapefile) formats. Both systems are standard database formats that are often used by the technical team of the Geospatial Information Agency. This format can be integrated with other thematic maps that have the same coordinate reference. This means that the maps in this atlas can be input to the process of analyzing in further research.

In the context of forming map layouts, a combination of science and cartographic art is used. Important elements in a map are not neglected such as titles, legend, north direction, scale, coordinates, and other elements (see Figure 2 to 4, the map of Indonesia, Central Java, and history). In certain pages, inserted other graphic information in the form of field photos and satellite imagery. The photos selection is based on the strategic value and uniqueness of the regional and historical themes displayed. For example, Indonesia is traversed by an imaginary line of the Equator so the photo displayed is the Equator Monument in the City of Pontianak at coordinates 0000 '00 "and $109^{\circ} 19^{\circ} 20^{\circ} \mathrm{E}$.

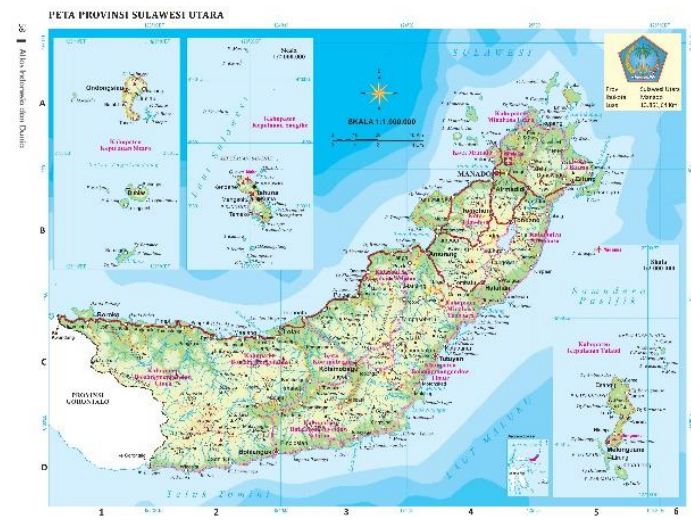

Figure 9. North Sulawesi Province

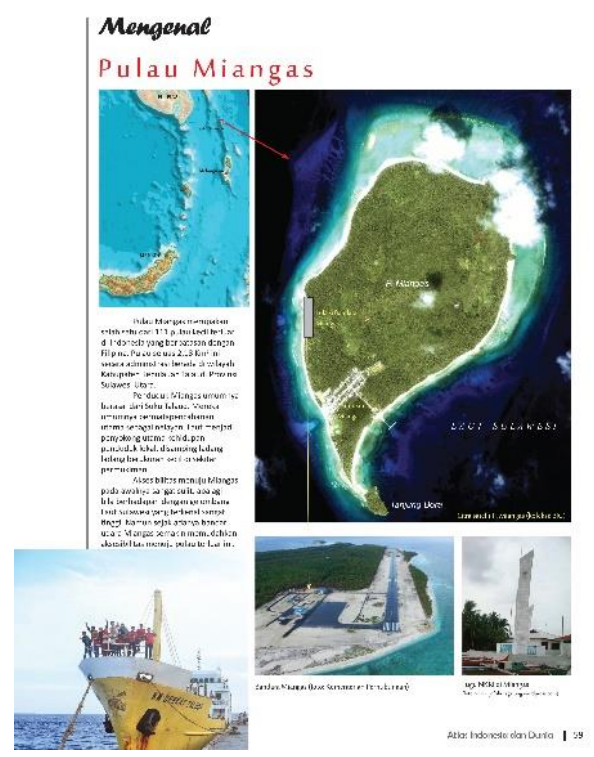

Figure 10. The distance of Miangas Island is closer to the Philipines

The satellite images selection that displayed in the atlas consider the strategic value of the object. For example Map of Sulawesi Province. This province has sea borders with the Philippines. The northernmost part is 
a small island called Miangas at coordinates 05033 '55"N and $126^{\circ} 34^{\circ} 58^{\circ} \mathrm{E}$. The distance of this island is closer to the General Santos City of the Philippines (89 nautical miles) compared to Manado City, the capital of North Sulawesi Province which reaches 265 nautical miles. In the context of the archipelagic state territory, the existence of Miangas Island is very vital because it concerning state sovereignty. In this context, an example of literacy about the area delivered to students.

Text information in the form of narrative text is an important part of this atlas. Narrative text becomes the source of information that explains a particular object. In Figure 10, there is a narrative text about Miangas Island which explains the strategic value information of the island in the context of Indonesia as an archipelagic state. In general, the percentage of text information is more in historical atlas than in the territorial atlas. The percentage comparison of maps (spatial) and non-spatial information of the territorial atlas is $90 \%$ and $10 \%$, while in the historical atlas ranges from $70 \%$ and $30 \%$.

All thematic maps and photo information, satellite images, and arranged narratives text are compiled into an atlas. The concept of the atlas is not a pile of meaningless maps, but geospatial information that arranged in a coherent and comprehensive manner. Therefore, the team arranged the contents according to the structure of the atlas that agreed in the focus group discussions.

\subsection{Atlas Readability Trial-Test}

An important step in producing quality atlases is arranging a trial-test workshop on the readability of the atlas. Before the workshop is held, printing test is important to do. This step is done to do the proofreading so that any errors in result printing could be known, for example, an error in colors different from those on the computer, the font that changed from the original, broken images, and other important things. The printed atlas then carried out by a review process in the atlas readability trial-test workshop.

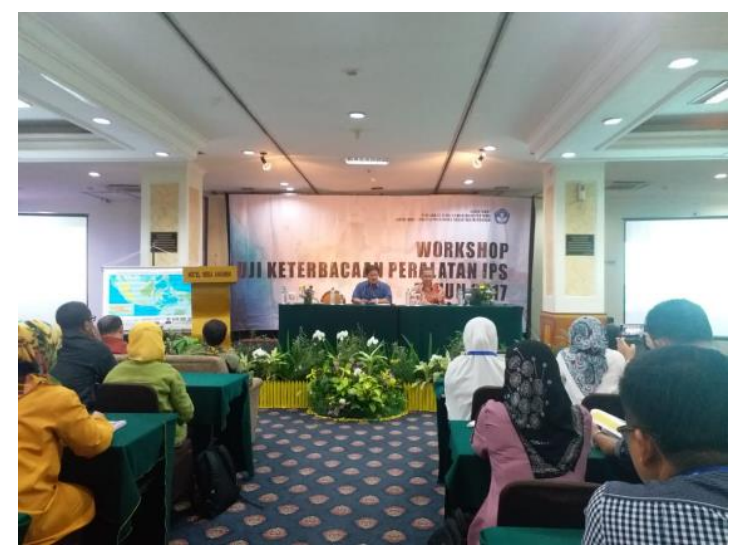

Figure 11. Atlas Readability Trial-Test Workshop

The atlas readability trial-test workshop involved representatives of Junior High School social studies practitioners from various regions in Indonesia, representatives of geography lecturers from universities, team of Center for Development and Empowerment of Educators and Education Personnel (P4TK), social science technical team from Directorate of Middle School Development, and mapping team from Geospatial Information Agency. The content reviewed concerning as follows:

1) Correction of the map data frame and the marginal information, including coloring aspects, text writing, terms, images, graphics, and other technical matters

2) Content material review, congeniality with the curriculum and learning requirements of junior high school social studies

3) Recommended improvements in either reduction or addition of atlas content.

One important input obtained during the workshop is that the level of readability of the map/atlas must be clear, simple, unambiguous, and entirely practical considering the target of the atlas user is students who have only reached the average age of 12-15 years, the range of juvenile age.

\subsection{Atlas Distribution and Dissemination}

The Territorial and Historical Atlas for Junior High Schools that have been successfully completed has been socialized through various media. First, printed atlas books and e-books were distributed to approximately 3,500 junior high schools in Indonesia through the Indonesian Ministry of Education and Culture. Second, the dissemination through network/online media can be accessed from the website: https://atlas.big.go.id/eatlas1/. This media can be accessed for alternative and interactive learning facilities for students.

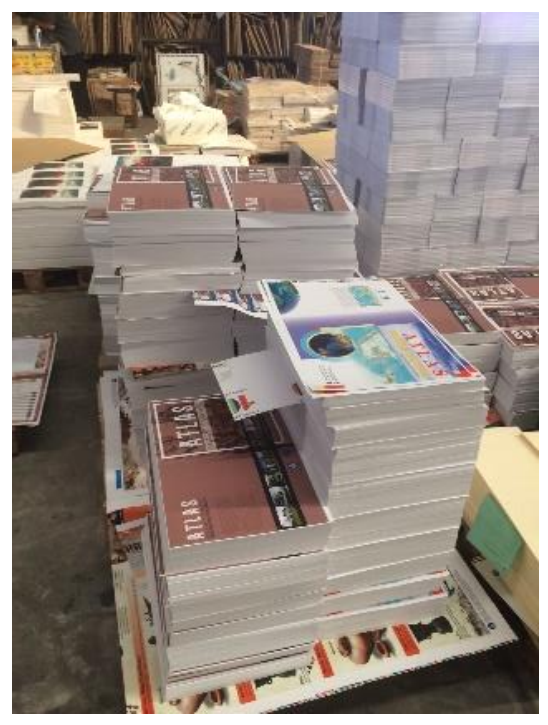

Figure 12. The mass production process of Indonesian Territorial and Historical Atlas

Media of atlas that varies from hardcopy, softcopy to an online electronic atlas that conducted in this activity considering that Indonesia is an archipelago. Some areas 
are familiar with the internet, on the other hand, most of the others are still not accessible to the internet. Online atlas can be accessible to those who have good internet connection access, for others who are not accessible to the internet, they are given a printed book atlas. Online atlas and printed atlas books are part of learning geoliteracy in the class.

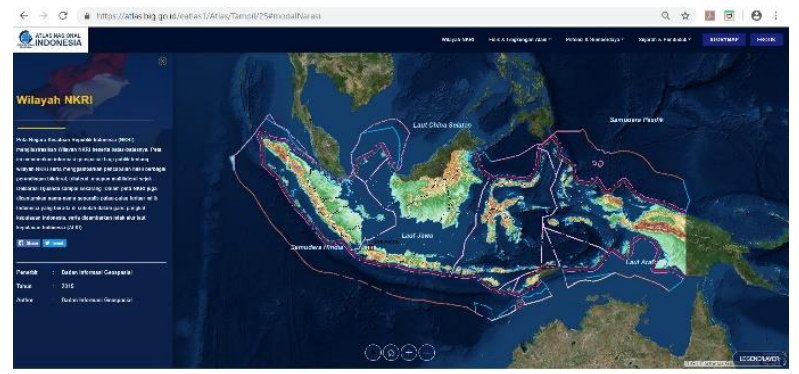

Figure 13. Online atlas website

\section{Conclusions and Recommendations}

The Republic of Indonesia Territorial and Historical Atlas are structured comprehensively and interrelated between regions, both nationally or internationally so that the element of connectivity between spaces is fulfilled according to the mandate of the National Education Curriculum in Indonesia. Media atlas in printed books, ebooks, and online atlas are estimated as an effective way of learning in the classroom and as a method in supporting national literacy programs. In this case, support for strengthening national literacy is in the form of spatial aspect learning (geo-literation).

\section{Acknowledgements}

The Geospatial Information Agency team would like to thank the Directorate of Junior High School Development, the Directorate General of Primary and Secondary Education, the Ministry of Education and Culture of the Republic of Indonesia, which has collaborated both in developing the atlases and disseminating these products to thousands of schools in Indonesia.

\section{References}

Bachtiar, T. (2018, November 30). Geoliterasi. Retreived from https://www.pikiran-rakyat.com/kolom/2018/11/ 30/ geoliterasi-433872 on March 15, 2019.

International Cartographic Association. (1998). Atlas Production for Southeast Asia: Vol 2 the Proceedings of International Wokshop/Seminar 'Modern Cartography for Navigating the Information Highway' held in Bandung, Indonesia March 3-14, 1997.

The Ministry of Education and Culture of the Republic of Indonesia. (2014). Curriculum 2013 Implementation (Implementasi Kurikulum 2013). Press Workshop. Pondok Cabe, January 14, 2014.

Koop, R.O. (1993). Tools for the Electronic Production of Atlases. pp 129-137 in: I. Klinghammer e.a. (eds). Proceeding of the Seminar on Electronic Atlases, held in Visegrad, 1993. Budapest: Eotvos Lorand University.

Kraak, M.J and Ormeling, F. (2003). Cartography: Visualization of Geospatial Data. Second Edition. Pearson Education Limited.

Mustofa, F. (2016). Atlas, Front Gate of Geospatial Information (Atlas, Gerbang Depan Informasi Geospasial). GEOtangkas Magazine Vol. 1. No. 2 2016 [10-15]

National Geographic. (2012). What is Geo-literacy?. Retreived from https://www.nationalgeographic.org/ media/what-is-geo-literacy/ on March 21, 2019

Ormeling, F. (2013). Thematic Cartography: Social and Economic Aspect (Kartografi Tematik: Aspek Sosial dan Ekonomi). Penerbit Ombak, Yogyakarta.

Prahasta, E. (2005). Basic Concepts of Geographic Information Systems (Konsep-konsep Dasar Sistem Informasi Geografis). CV. Informatika, Bandung.

Prasetyaningrum, T. D., Rahardjo, N., and Rosyadi, R. I. (2017). Production of Web-based Museum Tourism Atlas in Yogyakarta Special Region (Penyusunan Atlas Wisata Museum Berbasis Web Daerah Istimewa Yogyakarta). Jurnal Bumi Indonesia Volume 6 No 1 2017 [1-10].

Setiawan, I., Dedi, S., and A. Mushlih. 2016. Social Science for Junior High School (Ilmu Pengetahuan Sosial Untuk SMP/MTs). Jakarta: Kementerian Pendidikan dan Kebudayaan.

Soendjojo, H. and Riqqi, A. (2012). Kartografi. Penerbit ITB, Bandung. 